COVID-19 infection also require ventilatory support. ${ }^{1}$ CCHFV can also be transmitted to HCWs dealing with CCHF patients due to inadequate use of N95 masks, improper hand hygiene, and inappropriate removal of gloves, gowns, and masks after handling blood or tissue products of infected patients.

The WHO should collaborate with the Ministry of Agriculture and Forestry of Turkey to arrange programs to eradicate the tick population in areas where a high number of CCHF cases have been reported. Prevention measures against CCHF outbreaks in Turkey should focus on the education of individuals at increased risk of infection and the supply of personal protective equipment (PPE) to the at-risk population. Awareness campaigns regarding personal protective measures should be encouraged among the general public to avoid tick bites. People should be advised to wear light-colored clothing covering both arms and legs and to use insect repellents to minimize exposure to tick bites. Integration between clinicians and public health workers is required to control all aspects of the outbreak and to manage the growing health crisis in the country.

\section{Acknowledgments.}

Financial support. No financial support was provided relevant to this article.

Conflicts of interest. All authors report no conflicts of interest relevant to this article.

\section{References}

1. Leblebicioglu H, Ozaras R, Irmak H, Sencan I. Crimean-Congo hemorrhagic fever in Turkey: current status and future challenges. Antiviral Res 2016;126:21-34.
2. Karti SS, Odabasi Z, Korten V, et al. Crimean-Congo hemorrhagic fever in Turkey. Emerg Infect Dis 2004;10:1379.

3. Turkey records 13 Crimean-Congo hemorrhagic fever deaths year to date. Outbreak News Today website. http://outbreaknewstoday.com/turkeyrecords-13-crimean-congo-hemorrhagic-fever-deaths-year-to-date-37034/. Accessed June 29, 2021.

4. Zoonotic virus kills 13 since January in Turkey. Daily Sabah website. https:// www.dailysabah.com/turkey/zoonotic-virus-kills-13-since-january-in-turkey/ news. Accessed June 29, 2021.

5. Tipih T, Burt FJ. Crimean-Congo hemorrhagic fever virus: advances in vaccine development. BioResearch Open Access 2020;9:137-150.

6. Mehmood Q, Irfan M, Ogunkola I, Jaguga F, Ullah I. Rift Valley fever and COVID-19 outbreak in Kenya: a double whammy. Ethics Med Public Health 2021. doi: 10.1016/j.jemep.2021.100685.

7. Turkey reports 4,883 COVID-19 cases, 52 deaths. Daily Sabah website. https://www.dailysabah.com/turkey/turkey-reports-4883-covid-19-cases52-deaths/news. Accessed: June 29, 2021.

8. Jain S, Rocha IC, Maheshwari C, et al. COVID-19 in Brazil: the danger of overlapping crises. J Med Virol 2021;93:4090-4091.

9. Harapan H, Ryan M, Yohan B, et al. COVID-19 and dengue: double punches for dengue-endemic countries in Asia. Rev Med Virol 2021;31(2):e2161.

10. Pazarlı AC, Parlak Z, Ekiz T. COVID-19 and Crimean-Congo hemorrhagic fever: similarities and differences. Heart Lung 2020;49:892-893.

11. Woman becomes Turkey's first CCHF, COVID-19 patient, beats both. Daily Sabah website. https://www.dailysabah.com/turkey/womanbecomes-turkeys-first-cchf-covid-19-patient-beats-both/news. Accessed June 29, 2021.

12. Ahmed A, Tahir MJ, Siddiqi AR, Dujaili J. Potential of Crimean-Congo hemorrhagic fever outbreak during Eid Ul-Adha Islamic festival and COVID-19 pandemic in Pakistan. J Med Virol 2021;93:182-183.

\title{
Association between Crimean-Congo hemorrhagic fever (CCHF) and coronavirus disease 2019 (COVID-19): A systematic review
}

\author{
Resat Ozaras $\mathrm{MD}^{1}$ (1), Ahmet Dilek MD ${ }^{2,3}$ (1) , Mustafa Sunbul MD ${ }^{4}$ and Hakan Leblebicioglu $\mathrm{MD}^{5}$ (1) \\ ${ }^{1}$ Infectious Diseases Department, Medilife Health Group, Istanbul, Turkey, ${ }^{2}$ Intensive Care Unit, VM Medicalpark Samsun Hospital, Samsun, Turkey, ${ }^{3}$ Istinye \\ University, Faculty of Medicine, Istanbul, Turkey, ${ }^{4}$ Infectious Diseases Department, Samsun Liv Hospital, Samsun, Turkey and ${ }^{5}$ Infectious Diseases Department, \\ VM Medicalpark Samsun Hospital, Samsun, Turkey
}

To the Editor-We read the paper of Mehmood et al ${ }^{1}$ with great interest. Their letter was based on a newspaper report of novel coronavirus (COVID-19) and Crimean-Congo hemorrhagic fever (CCHF) coinfection, and its scientific basis is questionable.

As cited by Mehmood et al, we previously described the management scheme of CCHF in Turkey in detail. ${ }^{2}$ In 2003, a multidisciplinary advisory board including representatives of Ministry of Health and the Ministry of Food was established. The management of CCHF patients has been carried out in the referral hospitals determined by the Ministry of Health in every region of the country. The virologic diagnosis has been established by the National Reference Laboratory. Records of all CCHF patients are entered into the national CCHF database. Education

Author for correspondence: Hakan Leblebicioglu, E-mail: hakanomu@yahoo.com

Cite this article: Ozaras R, et al. (2022). Association between Crimean-Congo hemorrhagic fever (CCHF) and coronavirus disease 2019 (COVID-19): A systematic review. Infection Control \& Hospital Epidemiology, 43: 1727-1728, https://doi.org/ 10.1017/ice.2021.388 campaigns were organized for healthcare workers and those engaged in agriculture and animal husbandry in endemic regions. The World Health Organization (WHO), the European Center for Disease Prevention and Control (ECDC), the Food and Agricultural Organization of the United Nations (FAO) and the WHO collaborating Center at Porton Down, United Kingdom, are among the collaborative institutions, and the EpiSouth project, EDENext, ARBO-ZOONET CCH fever, and PREPARE are the networking projects involved in Turkey. ${ }^{2}$ As a result of these measures and studies, the case fatality rate of CCHF is much lower, $4.8 \%$, compared to countries in which CCHF is prevalent such as Pakistan (13.9\%) and Iran (17.6\%). ${ }^{3}$

We agree with the authors' comment that CCHF and COVID-19 have clinical symptoms in common. However, this is universal fact and is not restricted to the cases in Turkey. We performed a search according to the PRISMA guideline, using databases of PUBMED, SCOPUS, and Web of Science, and using the keywords "Crimean Congo Hemorrhagic Fever AND 
Table 1. Patients Coinfected With COVID-19 and CCHF Reported From Turkey

\begin{tabular}{|c|c|c|c|c|c|c|c|c|c|c|c|}
\hline Author & Age, y & Sex & $\begin{array}{c}\text { Signs \& } \\
\text { Symptoms }\end{array}$ & Examination & $\begin{array}{l}\text { Abnormal } \\
\text { Laboratory } \\
\text { Findings }\end{array}$ & $\begin{array}{c}\text { Tick } \\
\text { Exposure }\end{array}$ & COVID-PCR & CCHF-PCR & Thorax CT & Treatment & Outcome \\
\hline $\begin{array}{l}\text { Buyuktuna } \\
\text { SA, et al }{ }^{4}\end{array}$ & 35 & Female & $\begin{array}{l}\text { Fever, body } \\
\text { pain }\end{array}$ & $\begin{array}{l}\text { Body temperature } \\
38^{\circ} \mathrm{C} \text {, respiratory } \\
\text { rate } 22 \text {, other } \\
\text { examination is } \\
\text { normal }\end{array}$ & $\begin{array}{l}\text { Leukopenia, } \\
\text { thrombocytopenia, } \\
\text { increased levels of } \\
\text { ALT, AST, D-dimer, } \\
\text { CRP, prolonged } \\
\text { INR }\end{array}$ & Yes & + & + & $\begin{array}{l}\text { Cystic bronchiectasic } \\
\text { changes in apical, posterior, } \\
\text { and anterior segments of } \\
\text { upper lobe of the } \\
\text { right lung and superior and } \\
\text { posterior segments of lower } \\
\text { lobe of the left lung }\end{array}$ & Favipiravir & Survived \\
\hline $\begin{array}{l}\text { Dulger AC, } \\
\text { et al }^{5}\end{array}$ & 65 & Male & $\begin{array}{l}\text { Dry cough, } \\
\text { myalgia and } \\
\text { fever }\end{array}$ & $\begin{array}{l}\text { Oxygen saturation } \\
95 \% \text { on ambient } \\
\text { air, other } \\
\text { examination is } \\
\text { normal }\end{array}$ & $\begin{array}{l}\text { Pancytopenia, } \\
\text { increased levels of } \\
\text { ALT, AST, D-dimer }\end{array}$ & $\begin{array}{l}\text { Not } \\
\text { described }\end{array}$ & + & + & $\begin{array}{l}\text { Multiple bilateral peripheral } \\
\text { ground-glass } \\
\text { opacities }\end{array}$ & Favipiravir & Survived \\
\hline
\end{tabular}

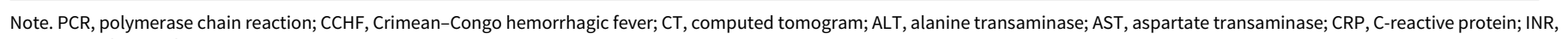
international normalization ratio.

COVID-19" without language and manuscript type restriction (PROSPERO registration CRD42021271507). The inclusion criteria were "patients with confirmed positive COVID-19 AND with confirmed positive CCHF. There remained 33 publications when duplications were removed. After screening titles and abstracts, 11 full-text articles were assessed for eligibility. Two case reports were included the final analysis after excluding the reports not meeting inclusion criteria. ${ }^{4,5}$ The analysis showed only 2 case reports of COVID-19 and CCHF coinfection from Turkey (Table 1$).{ }^{4,5}$ It is a rare occurrence.

Differential diagnosis of COVID-19 includes several viral and bacterial diseases such as influenza, adenovirus, human metapneumovirus, Mycoplasma pneumonia, Legionella pneumophila, and Streptococcus pneumoniae. ${ }^{6}$ In areas where CCHF is endemic, this viral disease is included in the differential diagnosis. CCHF may mimic multisystem inflammatory syndrome in children (MIS-C) associated with COVID-19. ${ }^{7}$ Severe COVID-19 pneumonia in adults has several clinical, laboratory, and radiographic features in common with CCHF.

Two reviews have discussed that the COVID-19 pandemic may have negatively affected the diagnosis and management of other illnesses, including CCHF. An additional 2 reports from Pakistan focused on the potential threat of CCHF due to mass gatherings during the Eid al Adha holiday. ${ }^{8,9}$ However, there is no evidence that CCHF cases increased following Eid al Adha in Turkey. One observational study noted increased CCHF cases after the COVID-19 pandemic began in 2020 compared to previous years in eastern region of Turkey..$^{10}$ On the other hand, the health infrastructure in the country allows the effective diagnosis and management of CCHF and no burden of CCHF or COVID-19 cases is overwhelming the capacity of the healthcare system in Turkey.

In conclusion, our systematic review showed that coinfected cases of COVID-19 and CCHF are rare. However, there appeared to be no difficulty with diagnosis, hospitalization needs, and treatment of the patients with CCHF during COVID-19 pandemic in Turkey, in contrast to the comment issued by Mehmood et al. ${ }^{1}$ The need for an evidence-based approach is clear.

\section{Acknowledgments.}

Financial support. No financial support was provided relevant to this article.

Conflicts of interest. All authors report no conflicts of interest relevant to this article.

\section{References}

1. Mehmood Q, Tahir MJ, Jabbar A, Siddiqi AR, Ullah I. Crimean-Congo hemorrhagic fever outbreak in Turkey amidst COVID-19 pandemic; a debacle for the healthcare system of Turkey. Infect Control Hosp Epidemiol 2021. doi: $10.1017 /$ ice.2021.343.

2. Leblebicioglu H, Ozaras R, Irmak H, Sencan I. Crimean-Congo hemorrhagic fever in Turkey: current status and future challenges. Antiviral Res 2016;126:21-34.

3. Leblebicioglu H, Ozaras R, Sunbul M. Crimean-Congo hemorrhagic fever: a neglected infectious disease with potential nosocomial infection threat. Am J Infect Control 2017;45:815-816.

4. Buyuktuna SA, Hasbek M, Oksuz C, et al. COVID-19 Coinfection in a patient with Crimean-Congo hemorrhagic fever: a case report. Mikrobiyoloji Bulteni 2021;55:445-451.

5. Dülger AC, Yakarişik M, Uzun YE, Şahin AM. Treatment of Crimean-Congo haemorrhagic fever by favipiravir in a patient with novel coronavirus coinfection. Eur J Case Rep Intern Med 2020;7: 002042.

6. Bordi L, Nicastri E, Scorzolini L, et al. Differential diagnosis of illness in patients under investigation for the novel coronavirus (SARS-CoV-2), Italy, February 2020. Euro Surveill 2020;25.

7. Yalçinkaya R, Polat M, Gümüşer Cinni R, Öz FN, Tanir G, Uysal Yazici M. Crimean-Congo hemorrhagic fever mimicking multisystem inflammatory syndrome in children associated with COVID-19: a diagnostic challenge. Pediatr Infect Dis J 2021. doi: 10.1097/INF.0000000000003269.

8. Ahmed A, Tahir MJ, Siddiqi AR, Dujaili J. Potential of Crimean-Congo hemorrhagic fever outbreak during Eid-Ul-Adha Islamic festival and COVID-19 pandemic in Pakistan. J Med Virol 2021;93:182-183.

9. Butt MH, Ahmad A, Misbah S, Mallhi TH, Khan YH. Crimean-Congo hemorrhagic fever and Eid Ul Adha: a potential threat during the COVID-19 pandemic. J Med Virol 2021;93:618-619.

10. Barkay O, Binay UD, Gül Ö, Karakeçili F. A significant increase in the number of Crimean-Congo haemorrhagic fever cases in the COVID-19 pandemic: what is happening? Klimik Dergisi 2020;33:197-198. 